Journal of Health Policy and Management (2018), 3(1): 26-33

https://doi.org/10.26911/thejhpm.2018.03.01.04

\title{
Determinants of Midwife Performance in Lactation Management in Surakarta and Karanganyar, Central Java
}

\author{
Nurul Wahidah'), Endang Sutisna Sulaeman'), Uki Retno Setia Budihastuti²) \\ 1)Masters Program in Public Health, Universitas Sebelas Maret \\ ${ }^{2)}$ Department of Obstetrics and Gynecology, Dr. Moewardi Hospital, Surakarta
}

\begin{abstract}
Background: Exclusive breastfeeding has been recommended by World Health Organization for reduction of infant illness and death. Midwives have an important role in lactation management, which includes: (1) Teaching all lactating mothers on how to successfully breastfeed and sustain it up to 2 years or more; (2) Coming in contact with mothers and infants to promote, protect, and support breastfeeding. However, exclusive breastfeeding coverage was still low at $80 \%$ nationally, $76.7 \%$ in Surakarta, and 61.1\% in Karanganyar in 2016, suggesting low midwife performance in lactation management. This study aimed to determine factors associated with midwife performance in lactating management in Surakarta and Karanganyar, Central Java.

Subjects and Method: This was an analytic observational study with a cross-sectional design. The study was conducted in community health center in Surakarta and Karanganyar, Central Java, from April to June 2018. A sample of 200 midwives was selected by simple random sampling. The dependent variable was performance in lactation management. The independent variables were skill, motivation, experience, health facility, and work load. The data were collected by questionnaire and analyzed by a multilevel logistic regression.

Results: Midwife performance in lactation management increased with better skill $(b=2.06$; $95 \% \mathrm{CI}=0.48$ to $3.65 ; \mathrm{p}=0.011)$, strong motivation $(\mathrm{b}=1.15 ; 95 \% \mathrm{CI}=-0.09$ to $2.41 ; \mathrm{p}=0.070)$, work experience $(b=2.06,95 \% \mathrm{CI}=0.69$ to $3.44, \mathrm{p}=0.003)$, and available facility $(\mathrm{b}=2.29,95 \%$ $\mathrm{CI}=0.89$ to $3.68, \mathrm{p}=0.001)$. Performance decreased with higher workload $(\mathrm{b}=-1.47 ; 95 \% \mathrm{CI}=-$ 2.76 to $-0.18, \mathrm{p}=0.025)$. Community health center had a contextual effect on midwives performance with ICC $=34.8 \%$.

Conclusion: Midwife performance in lactation management increases with better skill, strong motivation, work experience, and available facility. Performance decreases with higher workload. Community health center has a contextual effect on midwives performance.
\end{abstract}

Keywords: performance, lactation management, determinant, midwife

Correspondence:

Nurul Wahidah. Masters Program in Public Health, Universitas Sebelas Maret. Jl. Ir. Sutami No. 36 A, 57126, Surakarta, Central Java. Email: wahidahnurul246@gmail.com.

\section{BACKGROUND}

Lactation management is an attempt to support the exclusive breastfeeding of infants. The implementation of lactation management should begin during pregnancy, immediately after the delivery and during breastfeeding (Gay et al, 2013). The United Nations International Children's Emergency Fund (UNICEF) and the World Health Organization (WHO) recommended exclusive breastfeeding during the first six months of life to reduce morbidity and mortality rates. Exclusive breastfeeding is highly recommended because it is not contaminated and nutritious and suitable for infant ages, supplementary feeding at an early age may increase the risk of infants getting unhygienic food and may be malnourished and contaminated with infection, thus having a poor immune system (Ministry of Health, 2014). 
The presence of appropriate protective and nutrient factors in breast milk ensures good baby's nutritional status as well as decreases the morbidity and mortality of the children. Some epidemiological studies suggest that breast milk protects infants and children from infectious diseases, such as diarrhea, otitis media (ear infections), cough, colds, acute respiratory infections (ISPA) and allergies (Lok et al., 2017). The nutritional content contained in colostrum has 10-17 times greater than mature milk. According to study conducted by Bhutta and Kumar (2013); Lamberti et al., (2013); Hanieh et al. (2015), in a number of developing countries, it is concluded that exclusive breastfeeding can reduce morbidity and mortality because of diarrhea and pneumonia. Breastfeeding in the first hours of infant life or Early Breastfeeding (EBF) has been shown to decrease neonatal mortality (Bacolinia et al., 2013); (Victoria et al., 2017).

Exclusive breastfeeding coverage in Indonesia in Infants 0-6 Months fluctuated within 3 years ie in 2013: 48.6\%, s 2014: 54.3\% and 2015: 41.9\% (Ministry of health, 2016). The coverage of exclusive ASI in Central Java is 41,3\%, Surakarta City 2014 is $67.7 \%, 2015$ is $72.9 \%$ and in 2016 exclusive ASI Surakarta is $76.7 \%$, and an increase in exclusive breastfeeding in the Surakarta City Region, and on average the achievement of Surakarta City Region exclusivity is almost close to the national target of 80\% (Health office of Surakarta, 2016). Karanganyar District Health Office data shows that in 2013 exclusive breastfeeding coverage of $14.93 \%$ and then increased to $25.12 \%$ in 2014 and declined to $18.2 \%$ in 2015 . On average the achievements of exclusive breastfeeding in Karanganyar District is still far of the national target of 80\% (DHO Karanganyar District, 2016).
The implementation of lactation management in exclusive breastfeeding is inseparable from the role of midwife performance in Community Health Center as an effort of health service which has positive influence to the achievement of the exclusive breastfeeding. Lactation management aims to improve the exclusive breastfeeding effort of six months in infants such as through information and communication and education (IEC) to the wider community, especially pregnant women and breastfeeding mothers so that mothers are willing and able to breastfeed their babies exclusively. Lactation management during the antenatal period is a strategic way for pregnant women who need health services to know their pregnancy and delivery preparation. Pregnant women should have at least four antenatal visits during pregnancy, and it is hoped that the visit will strengthen and empower the mother to be willing and able to exclusively breastfeed her baby, to motivate the mother to be confident that her breast milk is enough to give to her baby (Suryantini, 2008).

The achievement of exclusive breastfeeding in CHS in Surakarta has increased during the last three years, but it is unlike Karanganyar District which is still far from national target that is $80 \%$. The achievement of exclusive breastfeeding program targets in relation to midwife performance can be identified based on determinants of causes such as factors: skills and abilities. Sahito (2013) states that a person's ability and skill can have a good impact on the success and smoothness of an organization in order to achieve a particular goal. Research conducted by Tecla et al. (2017) reveal that facilities and infrastructure affect health service delivery and health personnel performance. Workload: workload affects a person's performance, work that demands too much The effectiveness 
Journal of Health Policy and Management (2018), 3(1): 26-33

https://doi.org/10.26911/thejhpm.2018.03.01.04

of a person's performance (Nurul, 2014), Motivation, Research (Weldegebriel et al., 2016) revealed that the motivation of health personnel reflects the interaction between health professionals and their work environment, potentially affecting the provision of health services, experience. Gibson (2010) describes that work experience can affect from one's performance, with experience then someone will be able to work better.

The success of exclusive breastfeeding is closely related to the presence of lactation management provided by health personnel. The role of health personnel is essential for training on lactation management. The performance of midwives who support the application of lactation management to the client or pregnant and lactating mothers will be able to increase the coverage of exclusive breastfeeding so that the baby will get the best nutrition of breast milk. Mother's Milk is the first vaccine and the best source of nutrition for infants, strengthens brain development, increases the lives of 520,000 children in the next 10 years (UNICEF, 2017); (World Alliance for Breastfeeding Action) (WABA, 2017), and is a unique source of nutrition that plays an important role in the growth, development and survival of infants (Erkul et al., 2010). Good nutritional status of children is given as early as possible since pregnancy because the condition and physical mother during pregnancy is very influential on milk production (Suryantini, 2008).

\section{SUBJECTS AND METHOD}

\section{Study Design}

This was an analytic observational study with a cross sectional design. The study was conducted in community health centers in Surakarta and Karanganyar, Central Java, from April to June 2018.

\section{Population and samples}

The target population was midwives in puskesmas (community health centers) in Surakarta and Karanganyar, Central Java. A total of 200 midwives from 28 puskesmas was selected by simple random sampling. As many as 28 puskesmas was selected by stratified random sampling.

\section{Study variables}

The dependent variable was midwife performance in lactation management. The independent variables were skill, health facility, workload, motivation, and experience.

\section{Operational definition of variables}

The midwife performance in the implementation of lactation management was defined as an effort to support the implementation of infant breastfeeding exclusively for six months. The implementation of lactation management should start during pregnancy, immediately after the delivery and breastfeeding. The measurement scale was continuous, but for the purpose of data analysis, it was transformed into dichotomous.

Skill was defined as midwife skill in giving and conducting lactation management service. The measurement scale was continuous, but for the purpose of data analysis, it was transformed into dichotomous.

Facility was defined as the availability of tools and places as the media in which midwife provide services. The measurement scale was continuous, but for the purpose of data analysis, it was transformed into dichotomous.

Workload was defined as the weight of midwife task. The measurement scale was continuous, but for the purpose of data analysis, it was transformed into dichotomous.

Motivation was defined as midwife willingness of someone to their task. Experience was defined as the length of 
work that has been taken by someone so that they will be able to understand the task or job well.

\section{Study instruments}

The data were collected using questionnaires. The validity test in this study was conducted on 30 midwives who work in Surakarta and Karanganyar. The reliability test was measured by Cronbach alpha.

\section{Data Analysis}

The characteristics of study subjects were indicated by the frequency and percentage. Bivariate analysis was conducted using Chi Square test. The relationship of variables studied was analyzed using multilevel analysis model. Variables at level one that directly affect the individual including skill, health facility, workload, motivation, and experience. The study variable at level two was puskesmas accreditation.

\section{Research ethics}

The research ethical licenses were obtained from the Research Committee at Dr. Moewardi hospital, Surakarta, Central Java. The research ethics include informed consent, anonymity, and confidentiality.

\begin{tabular}{|c|c|c|}
\hline & ULT & \\
\hline $\begin{array}{l}\text { 1. Characterist } \\
\text { Table 1. Study s }\end{array}$ & of $\mathrm{S}$ & cter \\
\hline Characteristics & $\mathbf{n}$ & $\%$ \\
\hline Age & & \\
\hline$\leq 40$ years old & 129 & 64.5 \\
\hline$>40$ years old & 71 & 35.5 \\
\hline Education & & \\
\hline$<$ Diploma III & 11 & 5.5 \\
\hline >Diploma III & 189 & 94.5 \\
\hline Residence & & \\
\hline$<10 \mathrm{Km}$ & 121 & 60.5 \\
\hline $\begin{array}{l}\geq 10 \mathrm{Km} \\
\text { Tenure }\end{array}$ & 79 & 39.5 \\
\hline$\leq 10$ years & 79 & 39,5 \\
\hline$>10$ years & 121 & 60,5 \\
\hline
\end{tabular}

Table 1 showed that most of the study subjects were at the age of $<40$ years (129, $64.5 \%)$. Most of study subjects were $\geq$ Diploma III $(189,94.5 \%)$, residence $<10$ $\mathrm{km}(121,60.5 \%)$, and tenure $\geq 10$ years (121, 60.5\%).

\section{Bivariate Analysis}

The results of bivariate analysis with Chi Square test in Table 2 showed that performance of midwives was affected by skill $(\mathrm{r}=0.95 ; \mathrm{p}=0.030)$, health facility $(\mathrm{r}=$ 1.06; $\mathrm{p}=0.008)$, workload $(\mathrm{r}=-1.01 ; \mathrm{p}=$ 0.015), motivation ( $\mathrm{r}=0.98 ; \mathrm{p}=0.014)$, and experience $(\mathrm{r}=0.87 ; \mathrm{p}=0.025)$.

Table 2. Results of bivariate analysis of factors associated with midwives performance

\begin{tabular}{lcc}
\hline $\begin{array}{c}\text { Independent } \\
\text { variable }\end{array}$ & $\mathbf{r}$ & $\mathbf{p}$ \\
\hline Skill & 0.95 & 0.030 \\
Facility & 1.06 & 0.008 \\
Workload & -1.01 & 0.015 \\
Motivation & 0.98 & 0.014 \\
Experience & 0.87 & 0.025 \\
\hline
\end{tabular}

\section{Multilevel Analysis}

Based on the results of multilevel analysis, it showed that the variables in the fixed effects group, skill was positively affected modwife performance. Higher skill increased performance $(b=2.06,95 \% \mathrm{CI}=$ 0.48 to $3.65, \mathrm{p}=0.011$ )

Facility was positively affected performance. Better facility increased performance $(b=2.29,95 \% \mathrm{CI}=0.89$ to 3.68, $\mathrm{p}=0.001$ ).

Workload was negatively affected performance. Higher workload decreased performance $(b=-1.47 ; 95 \% \mathrm{CI}=-2.76$ to $0.18 ; \mathrm{p}=0.025)$.

Motivation was positively affected performance. Strong motivation increased performance $(b=1.15 ; 95 \% \mathrm{CI}=-0.09$ to 2.41; $\mathrm{p}=0.070$ ).

Experience was positively affected performance. Had experience increased performance $(b=2.06 ; 95 \% \mathrm{CI}=0.69$ to $3.44 ; p=0.003)$. 
Journal of Health Policy and Management (2018), 3(1): 26-33

https://doi.org/10.26911/thejhpm.2018.03.01.04

Puskesmas accreditation status had performance with $\mathrm{ICC}=34.8 \%$.

strong contextual effect on midwife

Table 3. The result of multilevel analysis of factors that influence the performance of midwives in the implementation of lactation management

\begin{tabular}{|c|c|c|c|c|}
\hline \multirow{2}{*}{ Midwives Performance } & \multirow{2}{*}{ b } & \multicolumn{2}{|c|}{$95 \%$ CI } & \multirow{2}{*}{$\mathbf{p}$} \\
\hline & & Lower Limit & Upper Limit & \\
\hline \multicolumn{5}{|l|}{ Fix Effect } \\
\hline Ability & 2.06 & 0.48 & 3.65 & 0.011 \\
\hline Facilities and Infrastructure & 2.29 & 0.89 & 3.68 & 0.001 \\
\hline Workload & -1.47 & -2.76 & -0.18 & 0.025 \\
\hline Motivation & 1.15 & -0.09 & 2.41 & 0.070 \\
\hline Experience & 2.06 & 0.69 & 3.44 & 0.003 \\
\hline \multicolumn{5}{|l|}{ Random Effect } \\
\hline \multicolumn{5}{|l|}{ Puskesmas accreditation } \\
\hline \multicolumn{5}{|l|}{ Skill } \\
\hline \multicolumn{5}{|l|}{ Health facility } \\
\hline \multicolumn{5}{|l|}{ Workload } \\
\hline \multicolumn{5}{|l|}{ Motivation } \\
\hline Var (constants) & 1.76 & 0.47 & 6.46 & \\
\hline \multicolumn{5}{|l|}{ Observation score $=200$} \\
\hline \multicolumn{5}{|l|}{ log likelihood = -90.739 } \\
\hline \multicolumn{5}{|l|}{ ICC $=34.8 \%$} \\
\hline \multicolumn{5}{|l|}{ LR Test vs. Logistic Regresion } \\
\hline $\mathrm{p}<0.001$ & & & & \\
\hline
\end{tabular}

Community health center with a plenary accreditation status has a main purpose to increase the likelihood of having higher midwife performance than primary and basic health centers with no accreditation. Level of ability and skill, facilities and infrastructure of health center. Good motivation and experience increased the likelihood of having a higher midwife's performance than the lack of ability and skill, facilities and infrastructure of health center, motivation, and experience. A high level of workload would decrease the likelihood of having a decreased midwife's performance rather than low level of workload.

\section{The association between skill and performance}

Based on the result of the study, skill had a positive effect on midwife performance. Midwife with better skill tends to have good performance in providing health service.

This study is consistent with Isfahani et al. (2015) which stated that skill affected performance. Snowden et al. (2015) stated that skill could give a positive emotional impact in working.

\section{The association between facility} and performance

The results of this study showed that facility affected midwife performance in providing health services in health center. Facility was positively associated with performance.

This study is consistent with Putriningrum et al. (2016) which stated that if activities were facilitated by complete facilities and infrastructure, it would affect the success of a program. In addition, Sari (2016) also stated that work facility was a tool or infrastructure that was used to provide convenience in processing an input to the expected 
output. Therefore, if the facility was in good and complete condition, it could automatically grow work's enthusiasm of the employees in improving services to the community.

\section{The association between work- load and performance}

Based on the result of the study, there was a negative effect of workload on midwives performance. Midwife with heavy workload decreased midwife performance.

This study is consistent with Bogaert et al., (2014) that the workload could affect performance. A heavy performance would decrease performance. Lacey et al., (2007) stated that a deliberation or cooperation was needed in order to reduce the workload of each individual.

\section{The association between motiva- tion and performance}

Based on the result of the study, there was a positive effect of motivation on midwives performance. Higher motivation, the better performance. It can be assumed that midwife with strong motivation tends to provide health services.

This study is consistent with Djunawan et al., (2015), which stated that motivation could give a major impact on someone's performance. Haron et al., (2012) stated that motivation was very important for an individual to improve his/her performance. Szyrocka (2015) stated that motivation was one of the key factors in the success of an individual and organizational performance, by providing motivation in all individual, it would foster the spirit of an organization.

\section{The association between expe- rience and performance}

Based on the result of the study, there was a positive effect of experience on midwife performance. A person who has a lot of experiences would improve his/her performance compared to someone who has few experience. It can be assumed that respondents who have a lot of experiences tend to be easier in providing health services (performance).

This study is consistent with Fateme et al., (2016), which stated that someone's experience would give a good impact in providing services. Parker et al., (2014) stated that people who have worked for a long time would have a good experience than those who have never worked.

\section{REFERENCES}

Aninanya GA, Howard N, Williams JE, Apam B, Prytherch H, Loukanova S, Otupiri E (2016). Can performancebased incentives improve motivation of nurses and midwives in primary facilities in northern Ghana? A quasi-experimental study. Global HealthAction, 9(1). https://doi.org/10.3402/GHA.V9.32404

Bacolinia (2013). Breastfeeding during the first hour of life and neonatal mortality. Jornal de Pediatria, 89(2), 131136.https://doi.org/10.1016/j.jpe d.2013.03.005

Bhutta ZA, Das JK (2013). Global Burden of Childhood Diarrhea and Pneumonia: What Can and Should Be Done? Pediatrics, 131(4), 634-636. https//doi.org/10.1542/peds.2012-3737.

Birhanu Z, Assefa T, Woldie M, Morankar $S$ (2010). Determinants of satisfaction with health care provider interactions at health centres in central Ethiopia: a cross sectional study. BMC Health Services Research, 10(1): 78. https://doi.org/10.-1186/1472-6963-10-78.

Bogaert VP, Timmermans O, Weeks SM, van Heusden D, Wouters K, Franck E (2014). Nursing unit teams matter: Impact of unit-level nurse practice environment, nurse work characteristics, and burnout on nurse reported job outcomes, and 
Journal of Health Policy and Management (2018), 3(1): 26-33

https://doi.org/10.26911/thejhpm.2018.03.01.04

quality of care, and patient adverse events-A cross-sectional survey. International Journal of Nursing Studies, 51(8), 1123-1134. https://doi.org/10.1016/j.ijnurstu.2013.12.0 09.

Dinkes Kabupaten Karanganyar (2016). Profil Kabupaten karanganyar.

Dinkes Surakarta (2016). Profil Kota Surakarta tahun 2016.

Erkul et al. (2010). Evaluation of breastfeeding in a baby.Friendly city, Çorum, Turkey. Central European Journal of Public Health, 18(1), 3137.

Gay et al. (2013). Kecamatan Ternate Selatan Kota Ternate Maluku Utara Tahun 2013 Social Determinant Factors Affecting Lactation Management In Pregnant Women In Work Area Health Center Kalumata Southern District Of Ternate In North Maluku City Of Ternate In 2013 2Bagian Bio, (42).

Hanieh et al. (2015). Exclusive breast feeding in early infancy reduces the risk of inpatient admission for diarrhea and suspected pneumonia in rural Vietnam: A prospective cohort study Global health. BMC Public Health, 15(1), 1-10. https://doi.org/10.1186/s12889-015-2431-9

Haron (2016). The study of nurses' performance from the viewpoints of head nurses in the special and general wards of the instructional hospitals of Zahedan in 2015. International Journal of Medical Research \& Health Sciences, 5(9): 212-216.

Isfahani HM, Aryankhesal A, Haghani $\mathrm{H}$ (2014). The Relationship Between the Managerial Skills and Results of "Performance Evaluation" Tool Among Nursing Managers in Teaching Hospitals of Iran University of
Medical Science. Global Journal of Health Science. 7(2): 38-43. https://doi.org/10.5539/gihs.v7n2p38.

Kemenkes RI (2014). InfoDatin, Situasi dan analisis ASI EKSKLUSIF. Pusat Data Dan Informasi Kementerian KesehatanRI.https://doi.org/10.101 7/CBO9781107415324.004

Lamberti et al. (2013). Breastfeeding for reducing the risk of pneumonia morbidity and mortality in children under two: a systematic literature review and meta-analysis. BMC Public Health, 13(3). https://doi.org/10.1186/1471-2458-13-S3-S18.

Larson E, Hermosilla S, Kimweri A, Mbaruku GM, Kruk ME (2014). Determinants of perceived quality of obstetric care in rural Tanzania: a cross-sectional study. BMC Health Services Research, 14(1): 483. https://doi.org/10.1186/1472-696314-483

Lok et al, 2017. (2017). Family members' infant feeding preferences, maternal breastfeeding exposures and exclusive breastfeeding intentions. Midwifery, 53: 4954. https://doi.org/10.1016/j.midw.2017.07.003.

Parker V, Giles M, Lantry G, McMillan M (2014). New graduate nurses' experiences in their first year of practice. Nurse Education Today, 34(1): 150156. https://doi.org/10.1016/j.nedt.2012.07.003.

Putriningrum (2016). Exclusive Breast Feeding Management: Qualitative Study on Working Mothers in Kalibawang District, Kulon Progo, Yogyakarta, 13-19.

Sahito (2013). Keberhasilan Pemberian Asi Eksklusif. Jurnal Health Quality, 4(2): 77-141.

Sari UP (2016). Pengaruh Fasilitas, Lingkungan Kerja Dan Motivasi Terhadap Kinerja Pegawai Di Kantor 
Camat Sangatta Selatan Kabupaten Kutai Timur. eJournal Pemerintahan Integratif, 4(4), 505-519.

Snowden A, Stenhouse R, Young J, Carver H, Carver F, Brown N (2015). The relationship between emotional intelligence, previous caring experience and mindfulness in student nurses and midwives: A cross sectional analysis. Nurse Education Today, 35(1), 152-158. https://doi.org/10.1016/j.nedt.2014.09.004.

Suryantini SH (2008). Analisa Determinan Pelaksanaan Manajemen Laktasi Pada Pelayanan Antenatal, 2006 USU Repository (C) 2008.

Tecla SJ, Omenge OR, Priscah MJ (2017). Evaluating Provider's Knowledge Level on Basic Emergency Obstetric and Neonatal Care (BEmONC), West Pokot, 6(6): 44-52. https://doi.org/10.9790/19590606094452.

UNICEF (2017). Determined to breastfeed": A case study of exclusive breastfeeding using interpretative phenomenological analysis. Women and Birth, 30(4): 325-331. https://doi.org/10.1016/j.wombi.2017.01.0 02.

Victoria (2017). A prospective study of breastfeeding intentions of healthy weight and overweight women as predictors of breastfeeding outcomes. Midwifery. 53: 2027. https://doi.org/10.1016/j.midw.2017.07.002.

WABA 2017 (2017). Awareness of the Benefits and Practice of Exclusive Breastfeeding (EBF) among nursing mothers in Anyigba , North Central Nigeria. World Journal of Nutrition andHealth,5(1),15.https://doi.org/1 0.12691/jnh-5-1-1.

Weldegebriel (2016). Motivation of health workers and associated factors in public hospitals of West Amhara, Northwest Ethiopia. Patient Preference and Adherence. 10: 159-169. https://doi.org/10.2147/PPA.S9032 3 . 